\title{
Comparison of artificial neural network, fuzzy logic and genetic algorithm for cutting temperature and surface roughness prediction during the face milling process
}

\author{
Savkovic, B. ${ }^{a}{ }^{,}$, Kovac, P. ${ }^{a}$, Rodic, D. ${ }^{a}$, Strbac, B. ${ }^{a}$, Klancnik, S. ${ }^{b}$ \\ ${ }^{a}$ University of Novi Sad, Faculty of Technical Sciences, Department of Production Engineering, Novi Sad, Serbia \\ ${ }^{b}$ University of Maribor, Faculty of Mechanical Engineering, Production Engineering Institute, Maribor, Slovenia
}

\begin{abstract}
A B S T R A C T
This paper shows the possibility of applying artificial intelligence methods in milling, as one of the most common machining operations. The main goal of the research is to obtain reliable intelligent models for selected output characteristics of the milling process, depending on the input parameters of the process: depth of cut, cutting speed and feed to the tooth. One of the problems is certainly determining the value of input parameters of the processing process depending on the objective function, i.e. the output characteristics of the milling process. The selected objective functions in this paper are the temperature in the cutting zone and arithmetic mean roughness of the machined surface. The paper examines the accuracy of three models based on artificial intelligence, obtained through artificial neural networks, fuzzy logic, and genetic algorithms. Based on the mean percentage error of deviation, conclusions were drawn as to which of the three models is most adequately applied and implemented in appropriate process systems, which are based on artificial intelligence.

(c) $2020 \mathrm{CPE}$, University of Maribor. All rights reserved.
\end{abstract}

\begin{tabular}{l} 
A R T I C L E I N F O \\
\hline Keywords: \\
Artificial intelligence; \\
Artificial neural networks (ANN); \\
Fuzzy logic (FL); \\
Genetic algorithms (GA); \\
Face milling; \\
Modeling; \\
Surface roughness; \\
Cutting temperature \\
*Corresponding author: \\
savkovic@uns.ac.rs \\
(Savkovic, B.) \\
Article history: \\
Received 14 June 2019 \\
Revised 20 June 2020 \\
Accepted 23 June 2020
\end{tabular}

\section{References}

[1] Klancnik, S., Begic-Hajdarevic, D., Paulic, M., Ficko, M., Cekic, A., Husic, M.C. (2015). Prediction of laser cut quality for tungsten alloy using the neural network method, Strojniški Vestnik - Journal of Mechanical Engineering, Vol. 61, No. 12, 714-720, doi: $10.5545 /$ sv-ime.2015.2717.

[2] Fulemová, J., Řehoř, J. (2015). Influence of form factor of the cutting edge on tool life during finishing milling, Procedia Engineering, Vol. 100, 682-688, doi: 10.1016/i.proeng.2015.01.420.

[3] Simunovic, G., Simunovic, K., Saric, T. (2013). Modelling and simulation of surface roughness in face milling, International Journal of Simulation Modelling, Vol. 12, No. 3, 141-153, doi: 10.2507/IJSIMM12(3)1.219.

[4] Perez, C.J.L. (2002). Surface roughness modeling considering uncertainty in measurements, International Journal of Production Research, Vol. 40, No. 10, 2245-2268, doi: 10.1080/00207540210125489.

[5] Ferreira, R., Rehor, J., Lauro, H.C., Carou , D., Davim , J.P. (2016). Analysis of the hard turning of AISI H13 steel with ceramic tools based on tool geometry: surface roughness, tool wear and their relation, Journal of the Brazilian Society of Mechanical Sciences and Engineering, Vol. 38, 2413-2420, doi: 10.1007/s40430-016-0504-z.

[6] Efkolidis, N., Hernández, C.G., Talón, J.L.H., Kyratsis, P. (2018). Modelling and prediction of thrust force and torque in drilling operations of Al7075 using ANN and RSM methodologies, Strojniški Vestnik - Journal of Mechanical Engineering, Vol. 64, No. 6, 351-361, doi: 10.5545/sv-jme.2017.5188.

[7] Hrelja, M., Klancnik, S., Balic, J., Brezocnik, M. (2014). Modelling of a turning process using the gravitational search algorithm, International Journal of Simulation Modelling, Vol. 13, No. 1, 30-41, doi: 10.2507/IISIMM13 11) 3.248 . 
[8] Ojstersek, R., Lalic, D., Buchmeister, B. (2019). A new method for mathematical and simulation modelling interactivity: A case study in flexible job shop scheduling, Advances in Production Engineering \& Management, Vol. 14, No. 4, 435-448, doi: 10.14743/apem2019.4.339.

[9] Sekulic, M., Pejic, V., Brezocnik, M., Gostimirović, M., Hadzistevic, M. (2018). Prediction of surface roughness in the ball-end milling process using response surface methodology, genetic algorithms, and grey wolf optimizer algorithm, Advances in Production Engineering \& Management, Vol. 13, No. 1, 18-30, doi: 10.14743/apem2018. $\underline{1.270}$.

[10] Meireles, M.R.G., Almeida, P.E.M., Simoes, M.G. (2003). A comprehensive review for industrial applicability of artificial neural networks, IEEE Transactions on Industrial Electronics, Vol. 50, No. 3, 585-601, doi: 10.1109/ TIE.2003.812470.

[11] Balic, J., Korosec, M. (2002). Intelligent tool path generation for milling of free surfaces using neural networks, International Journal of Machine Tools and Manufacture, Vol. 42, No. 10, 1171-1179, doi: 10.1016/S08906955(02)00045-7.

[12] Azouzi, R., Gullot, M. (1997). On-line prediction of surface finish and dimensional deviation in turning using neural network based sensor fusion, International Journal of Machine Tools and Manufacturing, Vol. 37, No. 9, 1201-1217, doi: 10.1016/S0890-6955(97)00013-8.

[13] Singh, A.K., Panda, S.S., Chakraborty, D., Pal, S.K. (2006). Predicting drill wear using an artificial neural network, The International Journal of Advanced Manufacturing Technology, Vol. 28, No. 5, 456-462, doi: 10.1007/s00170004-2376-0.

[14] Zuperl, U., Cus, F., Zawada-Tomkiewicz, A., Stępień, K. (2020). Neuro-mechanistic model for cutting force prediction in helical end milling of metal materials layered in multiple directions, Advances in Production Engineering \& Management, Vol. 15, No. 1, 5-17, doi: 10.14743/apem2020.1.345.

[15] Savković, B., Kovac, P., Gerić, K., Sekulić, M., Rokosz, K. (2013). Application of neural network for determination of cutting force changes versus instantaneous angle in face milling, Journal of Production Engineering, Vol. 16, No. 2, 1-4.

[16] Lin, S.C., Ting, C.J. (1996). Drill wear monitoring using neural networks, International Journal of Machine Tools and Manufacture, Vol. 36, No. 4, 465-475, doi: 10.1016/0890-6955(95)00059-3.

[17] Liu, T.I., Chen, W.Y., Anantharaman, K.S. (1998). Inteligent detection of drill wear, Mechanical Systems and Signal Procesing, Vol. 12, No. 6, 863-873, doi: $\underline{10.1006 / \mathrm{mssp} .1998 .0165 .}$

[18] Zuperl, U., Čuš, F., Kiker, E. (2006). Intelligent adaptive cutting force control in end-milling, Tehnički Vjesnik Technical Gazzete, Vol. 13, No. 1-2, 15-22.

[19] Zadeh, L.A. (1965). Fuzzy sets, Information and Control, Vol. 8, No. 3, 338-353, doi: 10.1016/S0019-9958(65) 90241-X.

[20] Sivarao, S., Brevern, P., El-Tayeb, N.S.M., Vengkatesh, V.C. (2009). GUI based Mamdani fuzzy Inference system modeling to predict surface roughness in laser machining, International Journal of Electrical \& Computer Sciences IJECS-IJENS, Vol. 9, No. 9, 281-288.

[21] Rajasekaran, T., Palanikumar, K., Vinayagam, B.K. (2011). Application of fuzzy logic for modeling surface roughness in turning CFRP composites using CBN tool, Production Engineering, Vol. 5, No. 2, 191-199, doi: $10.1007 / \mathrm{s} 11740-011-0297-\mathrm{y}$.

[22] Savković, B., Kovač, P., Rodic, D., Gostimirovic, M., Pucovski, V., Holešovský, F. (2014). Application of ANFIS for modeling and prediction of the surface roughness for steel dificult to machining, In: Proceedings of $8^{s t}$ International Scientific Conference on Mechanical Engineering-COMEC, Faculty of Mechanical and Industrial Engineering, UCLV, Cuba, 1-11.

[23] Lo, S.-P. (2003). An adaptive-network based fuzzy inference system for prediction of workpiece surface roughness in end milling, Journal of Materials Processing Technology, Vol. 142, No. 3, 665-675, doi: 10.1016/S09240136(03)00687-3

[24] Ho, S.-Y., Lee, K.-C., Chen, S.-S., Ho, S.-J. (2002). Accurate modeling and prediction of surface roughness by computer vision in turning operations using an adaptive neuro-fuzzy inference system, International Journal of Machine Tools and Manufacture, Vol. 42, No. 13, 1441-1446, doi: 10.1016/S0890-6955(02)00078-0.

[25] Hany, F. (2003). Handwriting digit reorganization with fuzzy logic, Jurnal Teknik Elektro, Vol. 3, No. 2, 84-87.

[26] Kovac, P., Rodic, D., Pucovsky, V., Savkovic, B., Gostimirovic, M. (2013). Application of fuzzy logic and regression analysis for modeling surface roughness in face milling, Journal of Intelligent Manufacturing, Vol. 24, No. 4, 755762, doi: $10.1007 / \mathrm{s} 10845-012-0623-\mathrm{z}$.

[27] Kovac, P., Rodic, D., Pucovsky, V., Savkovic, B., Gostimirovic, M. (2014). Multi-output fuzzy inference system for modeling cutting temperature and tool life in face milling, Journal of Mechanical Science and Technology, Vol. 28, No. 10, 4247-4256, doi: 10.1007/s12206-014-0938-0.

[28] Balic, J., Kovacic, M., Vaupotic, B. (2006). Intelligent programming of CNC turning operations using genetic algorithm, Journal of Intelligent Manufacturing, Vol. 17, No. 3, 331-340, doi: 10.1007/s10845-005-0001-1.

[29] Batish, A., Bhattacharya, A., Kaur, M, Cheema, M.S. (2014). Hard turning: Parametric optimization using genetic algorithm for rough/finish machining and study of surface morphology, Journal of Mechanical Science and Technology, Vol. 28, No. 5, 1629-1640, doi: 10.1007/s12206-014-0308-y.

[30] Dorlin, T., Fromentin, G., Costes, J.-P. (2016). Generalised cutting force model including contact radius effect for turning operations on Ti6Al4V titanium alloy, International Journal of Advanced Manufacturing Technology, Vol. 86, No. 9-12, 3297-3313, doi: 10.1007/s00170-016-8422-x.

[31] Santos, M.C., Machado, A.R., Barrozo, M.A.S., Jackson, M. J., Ezugwu, E.O. (2015). Multi-objective optimization of cutting conditions when turning aluminum alloys (1350-0 and 7075 T6 grades) using genetic algorithm, International Journal of Advanced Manufacturing Technology, Vol. 76, No. 5-8, 1123-1138, doi: 10.1007/s00170-014$\underline{6314-5}$. 
[32] Sivasakthivel, P.S., Sudhakaran, R. (2013). Optimization of machining parameters on temperature rise in end milling of Al 6063 using response surface methodology and genetic algorithm, The International Journal of Advanced Manufacturing Technology, Vol. 67, No. 9, 2313-2323, doi: 10.1007/s00170-012-4652-8.

[33] Lukic, D., Milosevic, M., Antic, A., Borojevic, S., Ficko, M. (2017). Multi-criteria selection of manufacturing processes in the conceptual process planning, Advances in Production Engineering \& Management, Vol. 12, No. 2, 151-162, doi: 10.14743/apem2017.2.247.

[34] Borojević, S., Lukić, D., Milošević, M., Vukman, J., Kramar, D. (2018). Optimization of process parameters for machining of Al 7075 thin-walled structures, Advances in Production Engineering \& Management, Vol. 13, No. 2, 121232, doi: 10.14743/apem2018.2.278

[35] Stojanović, B., Ivanović, L. (2015). Application of aluminium hybrid composites in automotive industry, Tehnički vjesnik - Technical Gazette, Vol. 22, No. 1, 247-251, doi: 10.17559/TV-20130905094303.

[36] Kovač, P., Rodić, D., Pucovski, V., Mankova, I., Savkovic, B ., Gostimirović, M. (2012). A review of artificial inteligence approaches applied in inteligent processes, Journal of Production Engineering, Vol. 15, No. 1, 1-6. 


\section{APEM}

\title{
Primerjava umetne nevronske mreže, mehke logike in genetskega algoritma za napoved temperature rezanja in površinske hrapavosti med postopkom čelnega rezkanja
}

\author{
Savkovic, B..$^{a}{ }^{,}$, Kovac, P. ${ }^{a}$, Rodic, D. ${ }^{a}$, Strbac, B. ${ }^{a}$, Klancnik, S. ${ }^{b}$ \\ aUniversity of Novi Sad, Faculty of Technical Sciences, Department of Production Engineering, Novi Sad, Serbia \\ ${ }^{b}$ University of Maribor, Faculty of Mechanical Engineering, Production Engineering Institute, Maribor, Slovenia
}

\section{POVZETEK}

Ta članek prikazuje možnost uporabe metod umetne inteligence pri rezkanju, ki predstavlja enega najpogostejših postopkov obdelave. Glavni cilj raziskave je bil pridobiti zanesljive inteligentne modele za napoved izbranih izhodnih značilnosti procesa rezkanja $\mathrm{v}$ odvisnosti od vhodnih parametrov procesa: globine rezanja, hitrosti rezanja in podajanja na zob. Eden od problemov je zagotovo določanje vrednosti vhodnih parametrov postopka obdelave glede na ciljno funkcijo, torej izhodne značilnosti procesa rezkanja. Izbrani ciljni funkciji v tem prispevku sta bili temperatura $v$ območju rezanja in aritmetična sredina hrapavosti obdelane površine. Prispevek proučuje natančnost, pridobljeno s tremi modeli, ki temeljijo na umetni inteligenci: umetnimi nevronskimi mrežami, mehko logiko in genetskimi algoritmi. Na podlagi povprečne odstotne napake odstopanja so bili narejeni zaključki, kateri izmed teh modelov je najprimernejši za uporabo v ustreznih procesnih sistemih, ki temeljijo na umetni inteligenci.

(C) 2020 CPE, University of Maribor. All rights reserved.

\section{PODATKI O ČLANKU}

Ključne besede:

Umetna inteligenca;

Umetne nevronske mreže (ANN);

Mehka logika (FL);

Genetski algoritmi (GA);

Čelno rezkanje;

Modeliranje;

Hrapavost površine;

Temperatura rezanja

*Kontaktna oseba: savkovic@uns.ac.rs (Savkovic, B.)

Zgodovina članka:

Prejet 14. junija 2019

Popravljen 20. junija 2020

Sprejet 23. junija 2020 